\title{
A CLÍNICA PSICOLÓGICA E O PÚBLICO LGBT
}

\author{
Livia Gonsalves Toledo* \\ Tânia Pinafi $i^{* *}$
}

\section{Resumo}

Tendo como base os estudos recentes sobre as sexualidades e os gêneros e, em especial, os relativos à diversidade sexual, este artigo promove uma discussão ética sobre as vicissitudes da clínica psicológica com a população LGBT (lésbicas, gays, bissexuais, travestis e transexuais). Para tanto, problematizamos a construção sócio-histórica-cultural da homossexualidade e da heterossexualidade, as hierarquias das sexualidades e algumas açôes terapêuticas na clínica direcionada ao público não-heterossexual, tendo em vista a Resolução do Conselho Federal de Psicologia no 1/99 que estabelece normas de atuação para os psicólogos em relação à questáo da orientação sexual. Desse modo, matizamos o discurso da clínica usualmente orientada para o trabalho com pessoas heterossexuais, pensando de modo crítico o trabalho desenvolvido com sujeitos que transitam entre a vulnerabilidade e a invisibilidade devido a sua dissidência dos preceitos heteronormativos.

Palavras-chave: clínica psicológica; diversidade sexual; homossexualidade; ética.

\begin{abstract}
THE PSYCHOLOGICAL CLINIC AND THE LGBT PUBLIC

Basing on the recent studies about the sexualities and the gender and, specifically, the ones which are related to the sexual diversity, this article promotes an ethic discussion about the vicissitudes in the psychological clinic with LGBT (lesbian, gay, bisexual and transgender) population. Considering the Resolution of Federal Council of Psychology $n^{\circ} 1 / 99$, that establishes norms of performance for the psychologists which are related to the subject of the sexual orientation, we developed some discussions regarding the socio-historical construction of the homosexuality and about the heterosexuality, the hierarchies of the sexualities, and the therapeutic actions in the clinic addressed the to no-heterosexual public. Thereby, we diversify about the clinical discourse which is usually regulated by the
\end{abstract}

* Faculdade de Ciências e Letras de Assis, UNESP, SP, Brasil. E-mail: liviagtoledo@gmail.com.

** Faculdade de Ciências e Letras de Assis, UNESP, SP, Brasil. E-mail: tania.pinafi@gmail.com. 
work with heterosexual people, thinking critically the work is developed with people who are passing trough the vulnerability and invisibility because their unsuitability to the heteronormative precepts.

Keywords: psychological clinic; sexual diversity; homosexuality; ethic.

No século XIX, ao contrário dos séculos anteriores em que Deus ou o diabo eram os grandes responsáveis pelos erros e acertos do sujeito, a existência humana passou a ser cada vez mais norteada pela lógica empírica e cada vez menos guiada pelo conhecimento teológico. Isto porque, na passagem da Época Clássica para a Modernidade, mudanças profundas ocorreram a propósito da emergência da Ciência, transformando as regras e os procedimentos que sustentavam os enunciados no plano social. Cada vez mais, com o advento científico e tecnológico do século XVII, o mundo passou a ser investigado e indagado, se abrindo a materialidades questionáveis e perdendo seu caráter de causalidades teológicas. “Esse acontecimento exige diferentes concepçóes de matéria, de sujeito, de objeto e de conhecimento que implicam outros modos de relação do homem com o mundo, consigo próprio e com a vida. Não há mais interditos ao olhar humano, ele está livre para interrogar" (França, 2004, p. 9).

De acordo com Elsirik e Trevisan (2008), a moral dominante da Época Clássica passava a produzir os sujeitos a partir da culpa e da má consciência, à sombra da forte influência das normas da religião católica, ainda tão fundantes da moral contemporânea. $\mathrm{Na}$ modernidade, o homem passou a ser protagonista de suas ações e não mais as feitiçarias, as influências divinas ou demoníacas - eventos inexplicáveis para a consciência científica que vinha se desenvolvendo nos últimos séculos. "E isso não seria possível sem a construção da interioridade no sujeito, sem a privatização do desejo e a responsabilização dos seus atos. Cada pessoa passa a ser o grande senhor dos seus atos, mas também o grande bandido" (Elsirik \& Trevisan, 2008, p. 7). No entanto, naquele momento, a consciência convivia no antagonismo de dois sistemas de pensamento. De um lado, havia as regras ditadas pela "moral cristã que desejaria o apequenamento do homem, que valorizaria a vontade de poder de ponta-cabeça, voltada contra o próprio homem. [...] a moral da renúncia de si” (Elsirik \& Trevisan, 2008, p. 10). E, de outro, havia os novos valores morais que se formaram com a instauração da racionalidade científica, nos quais o homem ocupou o primeiro plano quando se viu capaz de dominar a "natureza". Seja como for, o que tal quadro evidencia é que todo momento histórico é contingente, produto de um processo e, portanto, passível de transformação, sendo que a mesma sentença se aplica aos sujeitos. De acordo com Elsirik e Trevisan (2008, p. 9): "A moral sempre fora uma ferramenta fundamental para os usos e os prazeres do poder. Entretanto, no século XIX, acentua-se ainda mais sua importância, com o 
advento de um sujeito interiorizado e consciencioso que encontra nos valores morais o substituto para o Soberano (aquele que decreta as normas) de outros tempos".

A subjetividade humana, produzida e moldada a partir do entorno social e das relaçóes de poder que se manifestam entre os sujeitos, grupos e instituiçóes, passa a ser entendida como um circuito fechado, natural e individual, e as normas estabelecidas e os chamados "bons costumes", dependentes do desejo e da vontade de cada ser humano. A consciência começa a ser a grande guardiã das regras e, especialmente, das regras daquele Deus que não é mais o responsável pelos atos do homem, mas o que ainda dita as regras que ele deve seguir.

Não é que os valores "entraram" no sujeito ou "saíram" de seu interior, mas passaram a ser produzidos pelo coletivo atravessado por preceitos sociais de fundamentaçôes ora científicas, ora religiosas, fazendo os homens sentirem as normas e a vigilância como próprias. Ou seja, o que se chama de subjetividade "é essencialmente social, e assumida e vivida por individuos em suas existências particulares" (Guattari \& Rolnik, 1996, p. 33; grifos do texto), e analisá-la é avaliar uma moral e, portanto, um social que passou a ser vivido de forma individual. Ainda, esses processos de subjetivação não são escolhidos voluntariamente, somos convocados, aproximados ou afastados, sutil ou violentamente induzidos, de forma consciente ou inconsciente, tudo a depender do momento histórico, cultural, social e das próprias experiências e vivências individuais de cada ser humano.

Segundo Guattari e Rolnik (1996, p. 33) os seres humanos estão sempre cotejando o que eles chamam de processos de individualização, "uma relação de alienação e opressáo, na qual o indivíduo se submete à subjetividade tal como a recebe", podendo, deste modo, ser caracterizado como um sujeito "normal".

Situado e construído a partir de todo esse contexto, para que o sujeito realize uma transmutação de valores é preciso não apenas enfrentar a moral vigente no campo social, mas também a moral inculcada no próprio sujeito, criando novos olhares sobre si. É a partir disso que pensaremos sobre um contemporâneo processo de subjetivação, de construçóes constantes de novos territórios existenciais e de repetidos embates com forças dominantes no registro social, que é a vivência da homossexualidade nos dias atuais.

\section{Das práticas sexuais por si mesmas à identidade homossexual como essência}

A antropóloga Gayle Rubin (1989, p. 141; tradução nossa), ao discutir a hierarquia sexual nas sociedades ocidentais modernas, póe em evidência que 
sua existência surge "[...] [da] necessidade de traçar e manter uma fronteira imaginária entre o sexo bom e mau". Suas reflexôes sobre as hierarquias sexuais se encontram, esquematicamente, representadas no que ela chamou de: "pirâmide erótica", estando no topo desta "pirâmide" os heterossexuais casados, monogâmicos e procriativos.

Não é novidade a diferença de status entre as pessoas que são heterossexuais e as que não o são. Contudo, o que é muito interessante no pensamento de Rubin (1989) são as distinçôes que faz das pessoas heterossexuais entre si e dos homossexuais entre seus pares. Há diferenças consideráveis entre os níveis ocupados pelos diversos sujeitos LGBTs em sua "pirâmide erótica", ainda mais quando se considera que somente uma pequena parte deles poderia se enquadrar no modelo que detém certa respeitabilidade e reconhecimento - casais estáveis de lésbicas e gays que não assumam identidades de gênero dissidentes das esperadas para seu sexo biológico, monogâmicos e que náo expressem sua afetividade e erotismo pelo sexo oposto em público. De acordo com Rubin (1989, p. 137; tradução nossa), "os indivíduos cuja conduta aparece no topo dessa hierarquia veem-se recompensados com o reconhecimento de saúde mental, respeitabilidade, legalidade, mobilidade física e social, apoio institucional e benefícios materiais", o que deixa de ocorrer à medida que se descende aos níveis inferiores. Isso ocorre devido à dicotomia do sexo e, consequentemente, dos gêneros existente em todas as sociedades. Não há sociedade humana em que não exista a categoria sexual (homem e mulher) vista como oposta e complementar. É nesse sistema sexolgênero (Rubin, 1989) que se baseia e se mantém a organização heterossexual da sexualidade - e a imposiçáo dela a todos os membros da sociedade. Desse modo, a hierarquia dos atos e desejos sexuais, controlados pela divisão dos sexos e dos gêneros das sociedades modernas, cria identidades de gênero e sexuais que acabam sendo hierarquizadas umas frente às outras, fazendo com que aquelas pessoas que seguem a heteronormatividade se situem no topo da pirâmide (Rubin, 1989).

Alguns dos estigmas que atualmente recaem sobre a homossexualidade foram produzidos séculos atrás no seio da cultura judaico-cristã, a qual julgou arbitrariamente os então chamados sodomitas - homens que tinham relações sexuais com outros homens. Mais tarde, com a instituição do discurso médico e psiquiátrico em fins do século XVIII, estas mesmas relações sexuais passaram a ser definidas pela designação patológica: homossexualismoํ. Também é digno de nota que homens que mantiveram relaçóes sexuais entre si foram perseguidos em alguns países da Europa pré-moderna, uma vez que este tipo de prática sexual era tido como ilícito, portanto criminoso. 
Deste modo, enquanto em um primeiro momento o que se julgava era mais os atos e comportamentos do sujeito do que o sujeito em si, com o advento do conhecimento biopsicomédico esta disposiçãa se inverte. Assim, não se diz mais de sançóes à ordem do pecado ou do crime que definiam penalidades para as infraçóes cometidas, num determinado espaço de tempo, por algumas pessoas, mas a algo mais danoso e perigoso, pois os sujeitos passam a ser vistos como vivendo em um estado permanente de doença.

Entre estes dois discursos, o judaico-cristão e o biopsicomédico, existem implicaçóes muito distintas. Para o primeiro, as relaçóes sexuais entre sujeitos do mesmo sexo biológico aconteciam, sobretudo, por causa das incitações demoníacas, portanto resultado de estímulos externos dos quais o sujeito não tinha consciência ou responsabilidade. Já para o segundo, que criou a sexualidade como uma entidade independente do ato sexual, os sujeitos eram dotados de uma interioridade que os tornava conscientes e responsáveis por seus atos. Além disso, este discurso localizava a homossexualidade no interior do sujeito. Para Rubin, um

estigma extremo e punitivo mantém em status inferior algumas condutas sexuais e, de fato, constitui uma sanção contra aqueles (as) que as praticam. As raízes da força deste estigma encontram-se nas tradiçóes religiosas ocidentais, mas a maior parte de seu conteúdo contemporâneo é resultado do opróbrio médico e psiquiátrico. [...] A medicina e a psiquiatria multiplicaram as categorias de condutas sexuais errôneas (Rubin, 1989, p. 137; tradução nossa).

De acordo com Rotello (1988, p. 70), essa "definição da homossexualidade como desvio dos padróes sexuais contribuiu muito para o surgimento da liberação gay" e a criação de uma identidade homossexual ${ }^{2}$. Por isso, para compreender os processos de subjetivação desses sujeitos, se faz imprescindível tecer considerações acerca do entorno social no qual estavam inseridos, isto é, a visão socialmente prevalecente em torno das práticas/relaçóes entre pessoas de mesmo sexo biológico em cada momento histórico. A título de exemplo, uma das crenças correntes é a ideia de promiscuidade entendida como uma das "essências da homossexualidade", especialmente a masculina, o que possui uma base histórica e com fundamentos diversos.

Sobre a constituição dessa identidade homossexual, Rotello (1988) pontua que, antes dos anos 1950, apenas os homossexuais masculinos afeminados eram considerados e se consideravam homossexuais. Deste modo, homens que pratica- 
vam sexo com homens e tinham aparência não afeminada e funções masculinas, ou seja, ativos, não eram vistos e tampouco se viam como homossexuais. Sobre esta questão Rotello afirma que há

provas convincentes de que antes da metade do século $[\mathrm{XX}]$ o comportamento sexual dos homossexuais era muitíssimo diferente do que se tornou mais tarde, de que, a partir de meados do século e depois, aconteceram mudanças fundamentais não apenas nas autopercepçóes e crenças dos homossexuais, como também nos hábitos sexuais, espécies e número de parceiros, e até nas maneiras de fazer sexo (Rotello, 1988, p. 56).

Nos anos 1960 e início dos anos 1970, nos Estados Unidos, com o crescimento urbano, os homossexuais masculinos criaram uma subcultura que tinha como base de identidade homossexual a relação sexual descomedida:

[...] ocorreram mudanças muito significativas no comportamento gay masculino [...]. Entre elas um nítido aumento do sexo anal com parceiros múltiplos, o aparecimento dos assim chamados grupos de alto risco formados por homens que praticavam níveis extraordinários de comportamentos sexuais de alto risco e um rápido aumento na quantidade de intercâmbios sexuais entre pessoas desses grupos de risco e o resto da população gay. [...] As instituiçóes centrais da cultura gay masculina emergente eram os bares e as saunas. [Parte dos gays,] acostumados ao sexo secreto e furtivo, convenceram-se facilmente que a liberação envolvia não a abolição da clandestinidade, mas a liberdade de ser tão clandestino quanto possível. [...] se a liberação significava a rejeição da reserva, então ser mais liberado significava rejeitar ainda mais restriçôes, e os mais liberados (isto é, os mais gays) eram aqueles sem nenhum tipo de reserva ou restriçóes (Rotello, 1988, pp. 22; 73-76).

É digno de nota que a liberação gay dos anos 1970 coincidiu com a liberação sexual da década anterior e "se tornou elemento central dela. [...] homossexuais e heterossexuais se dedicaram ao amor livre [...], mas os homossexuais (que não foram nem mais nem menos frívolos que os heterossexuais) foram julgados à parte" (Castañeda, 2007, p. 155). A depravação sexual foi atribuída aos homossexuais como uma essência, enquanto os heterossexuais tiveram-na como uma fase passageira de evolução de costumes da geração pós-guerra. Essa distinção, calcada em preceitos morais mais que científicos, induziu os especialistas da época 
(médicos, psiquiatras, psicólogos, etc.) a considerarem aqueles que se desviavam da norma heterossexual como doentes a serem curados. Deste modo, o homossexual foi visto como detentor de desejo incontrolável e, por isso, "representava um perigo para a sociedade por causa de seu gosto pela promiscuidade" (Castańeda, 2007, p. 155).

Fatores socioeconômicos também influíram sobremaneira no estilo de vida dos homossexuais e, por conseguinte, no modo como eram percebidos. De acordo com Castańeda (2007), em geral os homens do mundo industrializado usufruíam de rendas mais elevadas que as mulheres e, no caso de serem homossexuais, geralmente não tinham filhos e esposas, estando "expostos ao consumo desenfreado, do qual as conquistas sexuais em série são uma forma exacerbada" (Castańeda, 2007, pp. 156-157). O autor ainda diz que outro mecanismo que explica por que a promiscuidade homossexual tinha mais aderência junto a uma subcultura gay é o sócio-histórico: levando em conta que, em muitos países, a liberação sexual nunca chegou às mulheres, os homens podiam encontrar em outros homens condutas sexuais que as mulheres não admitiam (como o sexo oral e anal), por terem crescido dentro de uma moral sexual tradicional. Além disso, eles, em relaçóes homossexuais, não precisavam se preocupar com a gravidez e o casamento forçado. E, por fim, devido ao machismo, que constrói a hipotética crença de que os homens necessitam "acumular continuamente múltiplas conquistas sexuais, homo ou heterossexuais. Nessa visão, a autoestima e o poder diante de seus pares dependeriam de sua capacidade de conquista" (Castañeda, 2007, p. 157).

Aliás, ainda no que tange à "promiscuidade homossexual", vale destacar que a produção de uma identidade pautada no sexo descomedido e anônimo esteve presente somente na subcultura homossexual masculina dos grandes centros urbanos (Rotello, 1988). Assim, diante de tudo o que foi exposto, não se pode afirmar que a promiscuidade seja parte de uma natureza ou "essência do homossexual" masculino, pois ela é uma produção cultural sócio-historicamente localizada. Igualmente, qualquer tipo de pré-conceito, estigma ou estereótipo associado à homossexualidade deve ser lido a partir do contexto no qual foi instaurado, pois, deste modo, poder-se-ia melhor compreender tanto as percepçóes que os heterossexuais têm da identidade homossexual quanto a construção da subjetividade daqueles(as) que se desviaram da norma heterossexual.

Muitos homossexuais, diante da discriminação, acabam por adotar alguns estigmas e estereótipos ${ }^{3}$ em busca da afirmação de uma identidade e "[...] interiorizam e interpretam os papéis e as condutas que a sociedade espera deles" (Castañeda, 2007, p. 164), ou seja, assumem para si um tipo de performance 
identitária sexual ${ }^{4}$. Dessa forma, "essências" (previamente estabelecidas para um sujeito ou identidade) são instauradas enquanto normas, enquadrando modos específicos de existência aceitos dentro de um sistema hegemônico (no caso aqui, o sistema hegemônico da heterossexualidade), e se configuram em práticas discursivas que, em sua repetibilidade ${ }^{5}$, situam os sujeitos em territórios específicos. Para Hall, é

precisamente porque as identidades são construídas dentro e não fora do discurso que nós precisamos compreendê-las como produzidas em locais históricos e institucionais específicos, no interior de formaçôes e práticas discursivas específicas, por estratégias e iniciativas específicas. Além disso, elas emergem no interior do jogo de modalidades específicas de poder e são, assim, mais o produto da marcação da diferença e da exclusão do que o signo de uma unidade idêntica, naturalmente constituída, de uma "identidade" em seu significado tradicional - isto é, uma mesmidade que tudo inclui, uma identidade sem costuras, inteiriça, sem diferenciação interna (Hall, 2000, p. 109).

Para Butler (1993), é justamente a partir da repetibilidade do ato performático e dos atos discursivos que se forma a identidade (de gênero ou sexual, por exemplo). Ou, como pontua Friedman (2002), não se escolhe essa ou aquela identidade (como se escolhe uma roupa), mas nós é que somos "convocados" pelas normas discursivas a habitar essa ou aquela identidade (Friedman, 2002, p. 7). Assim é com os outros estigmas, estereótipos, formas de existências - não são naturais. As normas discursivas são produções e, por isso mesmo, muitos sujeitos resistem a elas criando processos de subjetivaçáo singulares, não hegemônicos. Igualmente, aqueles que as assimilam são passíveis de transformação.

Além disso, lembrando que as identidades emergem no interior do jogo de modalidades de poder e são o produto da marcação da diferença e da exclusão, dentro do regime de forças binário que organiza nossa cultura e sociedade, a maioria das definiçóes se formula pela contraposição de termos quando, por exemplo, ser homem é não ser mulher, de modo que o masculino se define a partir de uma negação de outro táo importante quanto ele. Ou, também, pela norma heterossexual que age por eliminação: ser hetero é não ser homo. De tal modo, dizer da oposição hetero-homo é elusivo porque "[...] a norma heterossexual opera por meio da problematização do que apenas aparentemente é seu oposto, sua irmã gêmea, a homossexualidade" (Miskolci, 2009, p. 271). 


\section{Efeitos das (e nas) subjetividades aprisionadas pela homofobia}

A supremacia da lógica heterossexual, que exclui e segrega a homossexualidade enquanto fenômeno social, frequentemente rechaça aqueles (as) que não se enquadram nas identidades sexuais e de gêneros atribuídas a cada um dos sexos. Assim, as pessoas que não se conformam aos ideais da heteronormatividade ${ }^{6}$ sofrem procedimentos de exclusão que, sobre a homossexualidade, chamamos de homofobia e convivem com a experiência social da abjeção, que tende a marcar profundamente suas subjetividades, principalmente no que se refere à percepção de si.

Segundo Marina Castañeda (2007, p. 46): "quando uma pessoa se reconhece homossexual, não existem benefícios visíveis. Ao contrário: abre-se diante dela um futuro isolado e marginalizado que provavelmente trará conflitos com a família e a sociedade. Assumir-se homossexual não parece uma volta ao lar, mas, antes, um exílio". Assim sendo, as pessoas que não se enquadram nas normativas de gênero e sexualidade da heterossexualidade inevitavelmente, em algum momento de suas vidas, sofrerão retaliações (zombarias, insultos, perseguição, violência etc.) e poderão ser relegadas ao ostracismo. Frente a este quadro, o conceito de homofobia tem instrumentalizado modelos interpretativos de análise destas consequências maléficas atreladas às constriçóes sociais dos sexos e dos gêneros da heteronormatividade.

De acordo com Borrillo (2001), o termo homofobia foi utilizado pela primeira vez nos Estados Unidos em 1971, por K. Smith, e podia ser entendido, em sua conceituação inicial, como a repulsa irracional, tal como o ódio por gays e lésbicas. $\mathrm{O}$ autor ainda pontua que as primeiras críticas sobre o termo foram de J. Boswell, o qual realizou uma análise etimológica mais detalhada: tendo homofobia o radical grego homos, equivalente a semelhante ${ }^{7}$, sugeriu que a homofobia poderia ser traduzida mais como "medo do semelhante" que como "medo de homossexuais". Diante disso, Boswell recomenda o termo homossexofobia como mais adequado etimologicamente. Porém essa forma de entender a homofobia a coloca como algo interior ao sujeito homofóbico - um medo (fobia) e repulsa individual da homossexualidade -, excluindo outras formas de hostilidade. Hudson e Ricket (citados por Borrillo, 2001, p. 22; tradução nossa) propuseram, então, a diferenciação entre homofobia e homonegatividade, definindo essa última como: “[...] não apenas [o] caráter de aversão e ansiedade próprios da homofobia no sentido clássico do termo, mas também e, sobretudo, [o] conjunto das atitudes cognitivas negativas sobre a homossexualidade no nível social, moral, jurídico e/ ou antropológico". 
Consideraremos então homofobia nesse sentido amplo, englobando sua dimensão pessoal de natureza afetiva (a recusa fóbica aos homossexuais) e sua dimensão cultural (a recusa da homossexualidade enquanto fenômeno psicológico e social) (Borrillo, 2001). Ou seja, podemos pensar a homofobia como uma patologia social que está encarnada no indivíduo. Entretanto, ainda é importante lembrar que a homofobia tem sua construção não apenas na heterossexualização do desejo, mas também na desigualdade entre os sexos e os gêneros. Por isso, não apenas os que têm práticas sexuais com o mesmo sexo ou evidenciam o seu desejo pelo mesmo sexo são vítimas da homofobia. Assim sendo, não se restringe aos homossexuais, mas, como anteriormente dito, a todos aqueles que não se encaixam na heteronormatividade. Tal como complementa Junqueira (2007, p. 152), as normas de gênero de Butler (2000) "[...] parecem operar aí com toda a sua força, evidenciando que a homofobia age e produz efeitos sobre todos os indivíduos, homossexuais ou não, mulheres e homens - caprichosamente sobre os homens heterossexuais". Borrillo complementa que a

homofobia se converte assim na guardiã das fronteiras sexuais (hetero/ homo) e de gênero (masculino/feminino). Por isso os homossexuais não são as únicas vítimas da violência homofóbica, que também atinge todos aqueles que não se aderem à ordem clássica dos gêneros: travestis, transexuais, bissexuais, mulheres heterossexuais com forte personalidade, homens heterossexuais delicados ou que manifestam grande sensibilidade (Borillo, 2001, p. 16; tradução nossa).

A homofobia é manifesta de maneiras diversas e atua sobre aqueles que fogem à norma heterossexual - como lésbicas, gays, bissexuais, travestis, transexuais e todos aqueles que vivenciam relaçóes afetivo-sexuais com pessoas do mesmo sexo e que resistem às normativas de gênero estabelecidas para seu sexo biológico. Isso ocorre devido à organização heteronormativa da sociedade, que pressupóe que todos deveriam ser heterossexuais e portar-se nos âmbitos da masculinidade no caso dos nascidos com o sexo biológico masculino e da feminilidade no caso dos nascidos com o sexo biológico feminino. Qualquer um que seja dissidente das normativas impostas sofre algum tipo de estigma (doente, anormal, devasso, insano, pecador, estranho etc.), quando não é constrangido, coagido, excluído, humilhado e sutil ou explicitamente violentado devido a sua diferença.

Por isso, não é de admirar que muitos gays e lésbicas busquem estabelecer uma "representação positiva" da homossexualidade por meio de uma aproxima- 
ção aos constructos dos gêneros instituídos pela lógica heterossexual. Por esse viés, a identidade homossexual do gay masculino e da lésbica feminina se estabelece como mais positivada em contraposição àquelas que transgridem as normativas de sexo/gênero: gays afeminados, lésbicas masculinizadas, bissexuais, travestis e transexuais. Portanto, pessoas cujos desejos e subjetividades não se enquadram nas normativas sexuais vigentes também podem salvaguardar as fronteiras binárias e hierárquicas dos gêneros.

A propósito do binário interdependente heterossexismo-homofobia, Miskolci pondera que,

no nível individual, o heterossexismo costuma ser bem-sucedido em criar subjetividades homofóbicas de maneira a fazer com que até pessoas que se interessam por outras do mesmo sexo identifiquem-se com a cultura normativa. Daí não ser surpreendente a constatação de que expressóes homoeróticas costumam se associar à homofobia internalizada, mantendo o desejo como o cerne de subjetividades cujo segredo se mescla ao temor de contradição com a ordem social (Miskolci, 2009, pp. 280-281).

Para o sociólogo francês Daniel Welzer-Lang (1994) o sexismo produz muitas das expressóes homofóbicas. A este respeito Welzer-Lang (2001, p. 470) menciona a homofobia "[...] pela misoginia de alguns homens homossexuais, ou pela utilização de sátiras homofóbicas contra alguns gays afeminados (as 'loucas'), que reproduzem para alguns, por jogo ou desprezo, os estereótipos da feminilidade". Como se vê, a homofobia não parte, exclusivamente, dos heterossexuais para os homossexuais, também pode habitar e ser manifesta por pessoas homossexuais a seus pares. Desse modo, não apenas os que têm práticas sexuais com o mesmo sexo ou evidenciam o seu desejo pelo mesmo sexo são vítimas da homofobia, pois a homofobia afeta todos aqueles que não se ajustam à heteronormatividade.

Entendendo o sujeito enquanto produto e produtor das relaçóes sociais em que está inserido, podemos ver a homofobia enquanto uma construção cultural e social que recai sobre todas as pessoas, sejam elas heterossexuais ou não, tanto no sentido de expressá-la (serem homofóbicas) como no sentido de serem afetadas por ela (vítimas dela - seja pela vivência da homossexualidade, ou pelas dissidências das normas de gênero). Uma vez que os sujeitos estão subjetivamente situados dentro de uma rede de opressão, tanto exterior quanto interior, deve-se ter como norte que o processo terapêutico demanda: por um lado, uma leitura particularizada que envolve aspectos intrínsecos ao seu processo de subjetivação, por outro, as influências do entorno social nos quais estiveram e estão localizados. 
No que se refere à homofobia presente nos heterossexuais, em alguns casos, quando ela vem acompanhada de forte rejeição e hostilidade direcionados aos homossexuais, este mecanismo de defesa atua permitindo-lhes negarem em si próprios qualquer desejo homossexual, usando do mecanismo da projeção para defender-se inconscientemente de qualquer traço, emoção ou pensamento incompatíveis com os valores heteronormativos - "[...] em vez de reconhecê-los em nós, os colocamos no exterior" (Castañeda, 2007, p. 147) -, fazendo dos homossexuais um bode-expiatório para a sociedade heterossexual pela projeçáo homofóbica. Assim, desejos homossexuais reprimidos podem ser projetados no exterior (Castañeda, 2007) com uma carga de virulência tão maior quanto maior for a necessidade de recusá-los. Por isso, não é incomum que os assassinatos por motivos homofóbicos sejam acompanhados por requintes de crueldade, o que torna a interrogação de Fernando Gabeira uma questáo crucial: "O que (os assassinos) estão tentando matar depois que sua vítima já morreu?” (citado por Trevisan, 1998, p. 152). Para Andrew Sullivan, uma

pessoa que carrega um cartaz dizendo "Deus odeia as bichas"; que acha repugnante qualquer associação com homossexuais simplesmente porque eles são atraídos por pessoas do mesmo sexo; que maltrata, despreza ou procura prejudicar os homossexuais porque acredita que eles não são completamente humanos; que persegue, assalta, ou assassina homossexuais por paixão, por medo ou por um ódio inexplicável, não é uma pessoa com um argumento. É uma pessoa com um sentimento. Não há nenhum argumento possível contra tal pessoa, pois um argumento não seria uma resposta apropriada (Sullivan, 1996, p. 28).

Nos últimos anos, são cada vez mais recorrentes notícias sobre crimes de ódio gestados no anseio homofóbico de combater aqueles(as), ou melhor, "aquilo" que teima em se fazer visível. Nesse sentido, por exemplo, observa-se que "a liberação gay é acompanhada de uma homofobia cada vez mais explícita, organizada e militante" (Castañeda, 2007, p. 147), pois, atualmente, é inegável que o bicho-papão da sociedade heterofóbica saiu da obscuridade do armário para a luz do dia. Castañeda fala, ainda, que a

homofobia preenche várias funçóes importantes nos heterossexuais. Legitima sua própria orientação sexual; os faz sentir que seus valores morais e seus costumes sexuais são naturais e até mesmo superiores; permite a eles se sentirem orgulhosos de sua masculinidade ou feminilidade. Sejam ou 
não felizes em suas relações amorosas, desfrutem ou não de sua vida sexual, pelo menos têm a satisfação de se sentir "normais". A homofobia tem como função primordial, portanto, "normalizar" a heterossexualidade e lhe dar um verniz de superioridade moral que, talvez, não existisse em outra situação (Castañeda, 2007, p. 146).

Em relação aos homossexuais, o peso da homofobia recai de outra forma. É o que chamamos de homofobia interiorizada, "a diferença subjetiva mais importante entre os homossexuais e os heterossexuais. [...] [que] constitui um fenômeno cultural que está longe de ser universal, e que se reveste de diferentes formas e significaçóes conforme o contexto" (Castañeda, 2007, p. 143). De acordo com o autor, "a maioria dos homossexuais na sociedade atual, mesmo aqueles que se aceitem como tais, carrega em si um conflito existencial permanente. A homofobia interiorizada não tem fim: ela ressurge, sob diferentes formas, ao longo do ciclo vital" (Castañeda, 2007, p. 143). Diante disso, Castañeda interroga: ora,

o que acontece quando uma pessoa é exposta, desde sempre, a certa ideia? Acaba por interiorizá-la: torna-a sua, adota-a sem mesmo se dar conta disso, como tantas outras ideias que acabam por fazer parte de sua educação. Assim, a homofobia torna-se "natural": torna-se um valor implícito e inconsciente, gerando reaçóes imediatas, automáticas e, aparentemente, instintivas (Castañeda, 2007, p. 146).

A homofobia presente na sociedade, bem como a homofobia interiorizada, pode levar muitos homossexuais a viverem em certo isolamento afetivo, sexual e social. Além disso, em alguns casos, "[...] pode provocar um esforço contínuo para compensar o 'defeito' da homossexualidade em outras áreas da vida” (Castañeda, 2007, p. 152). Neste caso, Castañeda (2007, p. 152) diz que o homossexual "pode (inconscientemente) tentar provar que é 'aceitável' apesar de tudo, segundo o critério da sociedade heterossexual. [...] Como qualquer minoria discriminada, tentará constantemente provar que pode satisfazer as demandas da maioria". Conforme Castañeda (2007, p. 148), "pode parecer estranho o fato de que um homossexual possa ter preconceitos ou sentir certa rejeição à homossexualidade, mas é um fenômeno muito generalizado”.

Dentre as diversas estruturas aprisionantes da homofobia, Sedgwick (2007, p. 26) elege o armário como "a estrutura definidora da opressão gay no século XX”, pois, como enfatiza, mesmo 
num nível individual, até entre as pessoas mais assumidamente gays, há pouquíssimas que não estejam no armário com alguém que seja pessoal, econômica ou institucionalmente importante para elas. Além disso, a elasticidade mortífera da presunçáo heterossexista significa que, como Wendy em Peter Pan, as pessoas encontram novos muros que surgem à volta delas até quando cochilam. Cada encontro com uma nova turma de estudantes, para não falar de um novo chefe, assistente social, gerente de banco, senhorio, médico constrói novos armários cujas leis características de ótica e física exigem, pelo menos da parte de pessoas gays, novos levantamentos, novos cálculos, novos esquemas e demandas de sigilo ou exposição (Sedgwick, 2007, p. 22).

Castañeda (2007, p. 151) diz que "muitos homossexuais cresceram e viveram em certo isolamento afetivo e social; e isso só pode limitar seu desenvolvimento social e profissional" e afetivo. Isso traz, portanto, dificuldades no âmbito dos relacionamentos sociais que no transcurso da vida dos homossexuais podem acarretar: isolamento, guetificação (dificuldade de se relacionar com "a maioria" heterossexual e dificuldade de criar relaçóes sociais com o sexo oposto), crença de não ser capaz de realizar algumas coisas ou, ao contrário, uma tentativa de ser o melhor para uma supercompensação (em uma autoexigência e perfeccionismo seja na escola, no trabalho, ou nas relaçóes), para citar apenas algumas das consequências mais comuns. Assim, estão sempre num esforço contínuo em se fazerem ver como "aceitáveis". Ainda sobre a homofobia nos homossexuais Castañeda assinala que a

homofobia desenvolve um papel muito diferente nos homossexuais. Suas formas e manifestações podem mudar no decorrer do ciclo vital, mas sempre estará presente de um modo ou de outro - pelo menos na sociedade atual. [...] frequentemente acontece, por exemplo, que os homossexuais desconfiem de seus próprios desejos ou sentimentos: eles podem lhes parecer perversos, sujos ou até mesmo perigosos. [...] O fato de uma pessoa rejeitar sistematicamente seus próprios desejos ou sentimentos acabará, com o tempo, afetando suas relaçóes com os outros e com ela mesma, sua vida sexual, e até mesmo sua saúde física (Castañeda, 2007, p. 148).

Castañeda (2007) fala que uma emoção frequentemente reprimida pelas pessoas que se relacionam com outras do mesmo sexo é a cólera, pois elas são 
objeto de agressóes contínuas. As gozações, piadas, etiquetas e desvalorizaçóes relativamente constantes e conscientes às quais são expostas no cotidiano, por conta da homofobia, obviamente que as afeta, sem levar em conta as humilhaçóes e violências verbais, psicológicas ou mesmo físicas de que são vítimas. "A pergunta a ser feita não é a de saber se tudo isso os afeta ou não - pois é evidente que sim -, mas a de saber o que fazem com a cólera que normalmente deveriam sentir" (Castañeda, 2007, p. 149). Assim, os homossexuais interiorizam a violência homofóbica (física ou emocional), reprimindo-a ou deslocando essa violência aos outros ou a si mesmos - produzindo depressão e atitudes autodestrutivas.

A tentativa de suicídio em adolescentes e jovens homossexuais é extremamente alta; e a homofobia é a grande vilã. De acordo com Hersch (1991, citado por Sanders, 1994, p. 228), jovens gays e lésbicas estão três vezes mais propensos a tentar o suicídio que os jovens heterossexuais, e até 30\% de todos os suicídios que ocorrem na adolescência podem estar relacionados com questóes de identidade sexual.

Para Cooklin e Barnes (1994), comportamentos destrutivos poderiam vir como uma tentativa de implementação de vida, de criação de possibilidades outras de existência. Segundo eles, alguns comportamentos dissidentes, como violência, furtos ou a tentativa de suicídio "podem ser uma tentativa, embora incompetente, e distorcida, de criar maior flexibilidade ou causalidade em um sistema rígido, sem um desafio direto à ordem social” (Cooklin \& Barnes, 1994, p. 293).

Esses sistemas rígidos, nos quais os sujeitos estão inseridos, podem estar na família, nas relaçóes no trabalho, na igreja, em uma clínica baseada em fundamentalismos morais e religiosos homofóbicos ou mesmo na própria forma que a pessoa homossexual vive sua vida, pautando-se em formas estigmatizantes da homossexualidade. A vivência da homossexualidade pode se expressar de forma irresponsável, como: colocar-se em situaçóes de risco em que possa sofrer violências homofóbicas ou práticas de sexo não-seguro, passando também pelo consumo descomedido de drogas e álcool - comportamentos possibilitados pela não-consciência da internalização da homofobia.

Geralmente essas atitudes são erroneamente interpretadas como uma disfunção própria da "essência homossexual" e não como um dos possíveis efeitos da homofobia sobre essas pessoas. Além disso, também fazem com que os homossexuais assumam estereótipos socialmente atribuídos a eles - gay drogado, gay promíscuo, gay afeminado, invertido(a), mulher-macho etc. -, levando-os a ter uma imagem desvalorizada de si, pois socialmente negativizados. Outros sintomas da homofobia interiorizada estão em certa disposição para a vergonha e na persecutoriedade pela extrema susceptibilidade em que os sujeitos homossexuais 
se encontram (certos psiquiatras e psicanalistas, por esses efeitos da homofobia também mal interpretados, falavam de tendências paranoicas nos homossexuais, referindo-se a essa extrema susceptibilidade).

Náo é para adequar o paciente LGBT à norma heterossocial vigente que deve se orientar o trabalho terapêutico, ou seja, no sentido de levá-lo à assunção de uma postura que seja a mais asséptica e palatável possível dentro dos padrôes heterossexuais, mas sim para forjar possibilidades que disparem processos de subjetivação singulares no lugar onde seu paciente náo consegue, ou seja, ajudar o paciente a produzir uma existência na qual sinta que pode habitar sem sofrer. Para tanto, o trabalho terapêutico náo deve se ancorar em preceitos morais, religiosos, ou pressuposiçóes heterossexistas que façam referência a um modelo predeterminado de normalidade, de qualquer espécie, em seus posicionamentos analíticos. Mas para que isso aconteça precisamos de uma psicologia que seja reflexo de um agenciamento coletivo, que dialogue com o caráter finito e delimitado historicamente dos empreendimentos humanos e que não procure adaptar os sujeitos a modelos fechados e universais de verdades absolutas, os quais implicitamente enquadram as pessoas em quadros preestabelecidos da organização social heterossexual.

\section{A clínica pautada em fundamentalismos morais e religiosos}

Vários foram os pilares estruturantes da patologização das pessoas que não se orientaram para a heterossexualidade e, por isso mesmo, variadas as formas pelas quais se buscou tratar desses sujeitos. De acordo com Sanders (1994), até alguns anos atrás eram de uso comum nos atos clínicos com pacientes homossexuais as intervençóes corporais como o eletrochoque e a medicalização, a utilização de técnicas behavioristas em que se empregava um condicionamento aversivo para "redesignar" uma pessoa para a heterossexualidade, a sugestão do contato com o sexo oposto e da busca por relacionamentos heterossexuais antes de gays e lésbicas aceitarem sua própria homossexualidade. Sobre esta questão Sanders (1994, p. 230) provocativamente diz: "imagine se o terapeuta sugerisse que seus clientes aparentemente heterossexuais devessem tentar a atividade com o mesmo sexo antes de decidirem a casar, criar uma família tradicional e assim por diante".

O despreparo da sociedade para lidar com as pessoas LGBTs ainda gera situaçóes coercitivas, como a internação involuntária em estabelecimentos particulares que, até os dias de hoje, apregoam serem "comunidades terapêuticas". 
De acordo com o promotor Lúcio Flávio de Faria, "pacientes que atravessaram os portôes dessas pseudoclínicas levados pela esperança das famílias de que voltariam 'curados' teriam sido submetidos às mais terríveis sessóes de crueldade" (Silva \& Zuba, 2009). Outra denúncia sobre situaçóes abusivas cometidas no intuito de "curar" a homossexualidade está relatada no blog do advogado Carlos Alexandre Neves Lima, assessor jurídico da Coordenadoria Especial de Direitos Sexuais (CEDS)/RJ.

Segundo informa o jornalista Márcio Lima, de Belo Horizonte, o Coordenador de Saúde do Sistema Penitenciário, Dr. Paulo César Sampaio, pertencente aos quadros da Secretaria de Administração Penitenciária do Governo do Estado de São Paulo, lhe afirmou que existem no Brasil cerca de 30 mil jovens aprisionados em clínicas porque a família é homofóbica e deseja obter a cura da homossexualidade (Lima, 2009).

Em relação à clínica psicológica, e mais especificamente à psicanálise, Jurandir Freire Costa nomeia alguns psicanalistas de "demonizadores", pois, ao tentar "descrever cientificamente" a homossexualidade (como distúrbio mental, neurose ou perversão), estáo, de fato, estigmatizando moralmente condutas sexuais as quais desaprovam (Costa, 1998). "Sob o véu da neutralidade e de um saber supostamente especializado, o terapeuta pode pensar e dizer quase qualquer coisa no campo da homossexualidade sem nunca ser questionado" (Castañeda, 2007, p. 167).

Costa (1998, p. 22) aponta ainda que Freud falou da homossexualidade de forma nuançada e "mostrou uma tendência à moderação raramente copiada por seus seguidores". Ainda, de acordo com o autor, a "intervenção psicanalítica tem algo mais importante a dizer: náo existe objeto adequado ao desejo, e deste ponto de vista tanto faz como tanto fez!" (Costa, 1998, p. 17). Portanto, a presença das "identidades sexuais" "obriga a psicanálise a descrever-se, de modo a alcançar uma melhor compreensão da 'subjetividade humana'” (Costa, 1998, p. 18).

Para Castañeda (2007), o terapeuta homofóbico é aquele que coloca em pauta a homossexualidade como causa dos problemas dos pacientes (a depressão, o alcoolismo, a paranoia etc.). Também, o terapeuta náo pode tratar seu paciente como se ele fosse heterossexual, pois ele não o é. Sendo homossexual, dentro de um contexto social homofóbico, consequências conflituosas podem ocorrer - não devido à homossexualidade, mas à homofobia -, e cabe ao terapeuta identificá-las. Isolar a homossexualidade de outras áreas de vida do paciente apenas exacerba a sua compartimentização. 
Estando a sociedade pautada pela heteronormatividade, é inegável que as produçôes de conhecimento científico trazem acentuado enfoque nesta normatividade, que se subentende por uma oposição moral entre bom/mau, certo/ errado, profano/sagrado, sadio/doente. Não é a finalidade aqui discutir acerca dos processos pelos quais se estabeleceu a oposição entre a crença na boa e má sexualidade, o são e o mal, o normal e o patológico, mas sim pôr em relevo a importância dos referenciais teóricos utilizados na abordagem de que se reveste o debate da sexualidade. Tecer reflexôes acerca dos instrumentos teórico-conceituais utilizados para pensar e interpretar a sexualidade é de importância capital, principalmente nas últimas décadas ${ }^{8}$, devido às numerosas e importantes transformaçóes que vêm ocorrendo no pensamento, nas instituiçóes e nas subjetividades. Das diferentes abordagens dadas, observam-se psicólogos que têm sua prática clínica orientada sob princípios religiosos no trato com a questáo da homossexualidade. Sobre essa questáo, o recente caso da psicóloga do Rio de Janeiro, Rozangela Alves Justino, é exemplar. Parte de entrevista realizada com a citada psicóloga explicita esse fato.

Como psicóloga, a senhora aprendeu que a sexualidade faz parte da identidade do sujeito, e assim deve ser compreendida na sua totalidade. Em que essa orientação se confronta com a sua formaçáo cristâ? $\mathrm{Na}$ Abraceh ${ }^{9}$ (Associação de Apoio ao Ser Humano e à Família) não estou na função de psicóloga. Mas não há qualquer confronto da minha profissão com a minha religião. Deus é o senhor de todo o conhecimento. Quando a ciência chega a uma verdade é porque ela está de acordo com as orientaçôes de Deus. A psicologia é a ciência do comportamento humano. A minha abordagem profissional é a linha existencialista, com formação em psicodrama. Concebo o homem como um ser bio-psico-sócio-cultural-espiritual. O homem faz parte da criação de Deus, e sua identidade sexual foi criada por ele, potencialmente heterossexual (Feliz, 2007, s.p.; grifos nossos).

Em outro trecho da mesma entrevista, ela diz:

A heterossexualidade é o padrão, já que o ser humano é um ser criado por Deus e ele náo tem uma forma para gerar homossexuais. Tanto a homossexualidade quanto a bissexualidade podem ser estados passageiros, passíveis de mudança, conforme a motivação daqueles que se estranham com desejos homossexuais. Tenho declarado que o movi- 
mento ativista pró-homossexualismo tem gerado uma doença social, o que chamo também de Complexo de Gabriela, já que proclama a inverdade de que pessoas nascem, crescem e vão estar sempre homossexuais (Feliz, 2007, s.p.).

Atualmente, no Brasil, a Psicologia tem uma Resolução do Conselho Federal de Psicologia (CFP) aprovada no ano de 1999 que estabelece que a homossexualidade não constitui doença, distúrbio ou perversão e que os psicólogos não exercerão qualquer ação que favoreça a patologização de comportamentos ou práticas homoeróticas, nem adotarão ação coercitiva tendente a orientar homossexuais para tratamentos não solicitados. Os posicionamentos de Rozangela Justino, além de homofóbicos, são antiéticos e por isso resultaram em processo ético aberto pelo Conselho Regional de Psicologia do Rio de Janeiro por irem contra a Resolução CFP no 01/99. Em entrevista à Revista Veja, quando indagada sobre essa questão, considera-se vítima do CFP.

Por que a senhora acha que o Conselho Federal de Psicologia está errado e a senhora está certa? Há no conselho muitos homossexuais, e eles estão deliberando em causa própria. $\mathrm{O}$ conselho não é do agrado de todos os profissionais. Amanhã ele muda. Eu mesma posso me candidatar e ser presidente do Conselho de Psicologia. Além disso, esse conselho fez aliança com um movimento politicamente organizado que busca a heterodestruição e a desconstrução social através do movimento feminista e do movimento pró-homossexualista, formados por pessoas que trabalham contra as normas e os valores sociais (Linhares, 2009, s.p.).

O conselho de ética do CFP impôs a Rozangela Justino uma censura pública, coadunando assim com a decisão anterior do Conselho Regional de Psicologia do Rio de Janeiro. Naquele momento, a Associação Brasileira de Gays, Lésbicas, Bissexuais, Travestis e Transexuais - ABGLT também fez representação junto ao conselho de ética do Conselho Regional de Psicologia do Rio de Janeiro requerendo a cassação do registro profissional de Justino.

Julgamentos de cunho moral e religioso, além de serem contraproducentes no trabalho clínico, especialmente (mas não só) com a população LGBT (lésbicas, gays, bissexuais, travestis e transexuais), geralmente incitam a estigmatização e discriminação, constituindo, assim, mais uma forma de preconceito; com a diferença que vêm disfarçados por trás de uma pseudo-neutralidade-científica. 
Há ainda pseudoprofissionais das ciências da saúde (psicologia, psiquiatria, médicos de família, enfermeiros, etc.) que, não atendendo as recomendaçóes feitas pela American Pshychological Association (APA) e ao bom senso e ética de uma profissão, cujo propósito é fomentar e prover a saúde física, mental e social das pessoas, decidem continuar psicopatologizando e estigmatizando as pessoas com uma orientação sexual distinta da majoritária. Suas argumentaçóes não levam em conta dados empíricos de estudos controlados e, sobretudo, não têm em conta as variáveis do respeito à vontade e à integridade da pessoa. Só assim podemos compreender por que durante muitos anos se tenha utilizado a terapia de conversão ou reparadora para conseguir devolver ao indivíduo sua "natureza saudável" como heterossexual (Tozer \& Mcclanahan, 1999, citado por López, s.d.; tradução nossa).

\section{A clínica ética e a população LGBT}

Para Gibson (1998), a intervenção na clínica é feita do rompimento de limites/fronteiras/bordas por meio de um intercessor, que pode ser definido como um agente disparador e mediador de movimento e rompedor de limites/fronteiras - como ideias sobre alguma coisa que causam transformação, criação.

O que a autora chama de "Clínica intercessora" é mediada por esse intercessor que está entre, que garante a "expansão da subjetividade pelo acréscimo da estranheza que afeta" (Gibson, 1998, p. 9). É uma clínica da ação do "eu", de caráter inovador e impacto inovador. É o intercessor que vai causar uma perturbação - não no sentido de distúrbio, ou de desequilíbrio, mas no sentido de um fenômeno desencadeador de mudança, de "propagar reaçóes em cadeia nos termos envolvidos, simultaneamente, imprevisivelmente" (Gibson, 1998, p. 10).

A perturbação rompe o mesmo, o habitual, criando perplexidades, um sem-número de sub-redes que desencadeiam a transformação do sujeito e do mundo no qual ele habita. $\mathrm{O}$ sujeito se incorpora de ação, o que possibilita uma organização criativa do sujeito e o faz exercer sua processualidade. Autocriar-se e recriar-se, inventar-se e reinventar-se, engendrar-se ao meio - à rede. Gibson (1998) fala que o "si" é vazio, por isso incessantemente produtor de efeitos.

Esse processo, que a autora chama de enação, permite a transitoriedade e incorporação de novas identidades no sujeito dentro das redes nas quais o sujeito transita ao longo de sua história. As identidades podem ser transitórias 
ou provisórias, criadas por recorrências, regularidades e repetições de vivências do sujeito. Essas, que Gibson (1998, p. 13) chama de "microidentidades", são o que cria um "sentido de si", "consciência de si", senso de "si mesmo". O "si mesmo" se manifesta de acordo com as microidentidades que o corpo incorpora junto ao mundo/relaçóes que vive (seus "micromundos"). Tal como pontua a autora:

O sentido mais ou menos forte de um "si" decorre do estar mais ou menos à vontade, confortável com o saber fazer (o savoir faire) neste micromundo. Saber fazer que é produto daquele senso comum da espécie, aliás as recorrências das experiências a que nos referimos anteriormente; os hábitos e manias adquiridos durante o trânsito num certo micromundo. A fluidez do trânsito em nossos micromundos diários é consequência da fluidez na instalação das microidentidades que cada um deles solicita. A plasticidade e "desapego" do Ser ao sentido de "si" são essenciais para o fluxo dos micromundos e a instalação das microidentidades (Gibson, 1998, pp. 13-14).

No caso da clínica com pessoas não-heterossexuais, um grande cuidado a ser tomado é a percepção da cristalização de uma identidade. Gibson (1998, p. 14) fala que na busca de um "si" fundamental e imutável, não-vazio, o sujeito cristaliza uma dessas microidentidades, que se torna forte e se impóe em todos os micromundos, impedindo a emergência de outras microidentidades. $\mathrm{O}$ vazio do si perde entáo sua qualidade de produtor de efeitos, pois está preenchido com uma microidentidade enrijecida.

A clínica não deve enrijecer seu paciente numa uma identidade rígida, seja ela homossexual ou heterossexual, mas deve produzir liberdade de fluxo plena de responsabilidades, permitindo possibilidades e outras configuraçóes do sujeito.

Cooklin e Barnes (1994), apresentando um modo de conceitualizar padrôes entrincheirados e enrijecidos, dizem que quando esses padróes são incongruentemente adaptativos podem precisar ser liberados por meio da discussão de áreas de tabu da vida às quais se relacionam. "A negação é uma importante estratégia na preservação de um segredo, e quanto mais assustador o segredo, mais forte tende a ser a negação" (Black, 1994, p. 360).

Uma clínica terapêutica que tem a intencionalidade de patologizar ou curar a homossexualidade pode ser vista como o que Cooklin e Barnes (1994, p. 293) chamam de "sistemas enrijecidos, organizados em torno de respostas incon- 
gruentes, inefetivas ou mesmo ultrapassadas". Ou seja, um sistema enrijecido pela heteronormatividade baseado em morais sexuais e na religião fundamentalista e organizado em torno da negação e negativação da homossexualidade ou das pessoas que a vivenciam.

De acordo com Sanders (1994), alguns cuidados devem ser tomados por terapeutas na clínica com o público não-heterossexual. Para ele, os terapeutas devem ajudar os indivíduos a refletir positivamente sobre suas experiências e relaçóes com outras pessoas do mesmo sexo, apoiando o paciente a reelaborar a negatividade de sua homossexualidade para uma positividade. $\mathrm{O}$ autor chega a falar até mesmo de incentivo ao ativismo. Para tal, o terapeuta deve convidar os pacientes a aliarem-se a sentimentos positivos de sustentação à vida, ajudá-los a verem a si mesmos como vítimas de ideias inculcadas de discriminação, homofobia e desigualdades de gênero e convidar seus pacientes a externalizarem seus sentimentos e pensamentos homofóbicos interiorizados. Sanders (1994 diz que em

seu livro The family that came in from the cold - a five point pan, Dahlheimer e Feigal (1991b) ${ }^{10}$ salientam diversas experiências importantes que os terapeutas podem ajudar seus clientes a manejar. Eles começam abordando a necessidade de que pessoas gays e lésbicas superem o isolamento emocional pessoal - o isolamento que convida à loucura e ao suicídio, sugerindo uma reconstrução de relacionamentos interpessoais aos quais as pessoas gays e lésbicas têm direito, mas como um novo tema de suficiência e poder pessoal (Sanders, 1994, p. 234).

Ainda, o terapeuta deve usar de uma linguagem não heteronormatizada, estar consciente de sua própria homofobia e suposiçóes sexistas e atento à sua manifestaçáo. Deve ajudar seu paciente a "sair do armário" sem risco e com interlocutores apropriados. Castañeda (2007) ainda aponta que o terapeuta náo deve tratar o paciente como se ele não fosse homossexual, compartimentando áreas da vida do paciente como se sua homossexualidade estivesse apenas na relação sexual. E, finalmente, estar continuamente atualizado sobre as tendências sociais e culturais que dizem respeito à homossexualidade e a legislação sobre o assunto.

Um outro ponto a ser comentado sobre essa questáo da prática clínica com o público não-heterossexual diz respeito à questão da orientação sexual do terapeuta. De acordo com Castańeda (2007, pp. 125-134), se o terapeuta for heterossexual, é preciso enfrentar seus preconceitos e, frequentemente, sua ig- 
norância, já que as vivências da homossexualidade e das relações com o mesmo sexo têm suas especificidades. Por outro lado, se o terapeuta for homossexual caberá o questionamento dos possíveis benefícios que possam advir da revelação da orientação sexual ao paciente. Sobre essa questão, a autora menciona que pesquisas nos EUA revelam que a maioria dos homossexuais prefere terapeutas homossexuais, pois há menos perda de tempo com explicação das especificidades da vivência da homossexualidade e menor desconfiança da homofobia do terapeuta.

Para Castañeda (2007), muitas vezes é preferível que o terapeuta seja homossexual se a homossexualidade for um tema central para a terapia, juízo que lança frente ao despreparo de muitos profissionais diante de questóes próprias da vivência homossexual. Este despreparo do terapeuta pode resultar em colocaçóes recheadas de "boas intençóes homofóbicas" devido a uma "ignorância bem-intencionada" do profissional não familiarizado com a temática da homossexualidade. Isso se dá devido ao pouco interesse dos terapeutas e futuros terapeutas no estudo mais aprofundado sobre a homossexualidade; e ao ensino insuficiente sobre esta temática, especialmente no ramo da psicanálise, na terapia de casal e da família, de acordo com Castañeda (2007). Sobre isso, ela diz que esta temática é abordada mais profundamente e de modo breve no quadro da psicopatologia e das perversões sexuais.

Este artigo não pretende esgotar a questão da clínica voltada à população LGBT ou qualquer pessoa vítima da homofobia, em qualquer de seus aspectos, mas promover uma discussão ética sobre as vicissitudes da clínica psicológica e problematizar esta temática que ganha cada vez mais destaque atualmente, pois, como

clínicos, nós podemos nos achar hospedados em um espaço entre perspectivas essencialistas e pós-modernas. Não obstante, nós já não podemos nos refugiar em teorias psicodinâmicas que excluem preocupaçóes sociais, culturais e outras problematizaçóes afins. Hoje, valores pessoais, opinióes e atitudes referentes aos modelos sob os quais um terapeuta atua são reconhecidos como parte do processo terapêutico (Drescher, D'Ercole \& Schoenberg, 2003, p. 2).

O objetivo da clínica voltada ao público LGBT não é fazer o homossexual viver feliz apesar de sua homossexualidade, mas, de fato, graças à homossexualidade (Castañeda, 2007, p. 169), não é fazer com que se sintam "normais" e sim que assumam e apreciem sua diferença. 


\section{Referências}

Áran, M., Peixoto-Júnior, C. A. (2007). Subversôes do desejo: sobre gêneros e subjetividade em Judith Butler. Cadernos Pagu, 28, 129-147.

Black, L. W. (1994). A AIDS e o segredo. In: E. Imber-Black (org.). Os segredos na família e na terapia familiar (pp. 351-364). Tradução de Denise Batista. Porto Alegre: Artes Médicas.

Borrillo, D. (2001). Homofobia. Barcelona: Bellaterra.

Butler, J. (1993). Bodies that matter: on the discursive limits of "sex". London: Routledge.

Butler, J. (2000). Corpos que pesam: sobre os limites discursivos do "sexo". In: G. L.Louro (org.). O corpo educado: pedagogias da sexualidade (pp. 151-172). Traduçáo de Tomaz Tadeu da Silva. Belo Horizonte: Autêntica.

Butler, J. (2003). Problemas de gênero: feminismo e subversão da identidade. Tradução de Renato Aguiar. Rio de Janeiro: Civilização Brasileira.

Castañeda, M. (2007). A experiência homossexual: explicaçôes e conselhos para os homossexuais, suas famílias e seus terapeutas. Tradução de Brigitte Hervot e Fernando Silva Teixeira Filho. São Paulo: A Girafa.

Cooklin, A. \& Barnes, G. G. (1994). Os tabus e a ordem social: novos encontros para a família. In: E. Imber-Black (org.). Os segredos na família e na terapia familiar (pp. 292-325). Tradução de Denise Batista. Porto Alegre: Artes Médicas.

Costa, J. F. (1998). A questão psicanalítica da identidade homossexual. In: R. B. Granã (org.). Homossexualidade: formulaçóes psicanaliticas atuais (pp. 15-27). Porto Alegre: Artes Médicas.

Drescher, J., D'Ercole, A. \& Schoenberg, E. (orgs.) (2003). Psychotherapy with gay men and lesbian: contemporary dynamic approaches. New York: The Haworth Press Inc.

Elsirik, M. F. \& Trevisan, J. F. (2008). A invenção do ressentimento no século XIX e os desafios da psicologia social no século XXI. Psicologia, ciência e profissão, 28(1), 4-17.

Feliz, C. (2007). Há uma ditadura gay no Brasil. Athos GLS (Notícias). Disponível em <http:// www.athosgls.com.br/noticias_visualiza.php?contcod=20600>. Recuperado em 29 de agosto de 2009.

França, S. A. M. (2004). Cenas do contemporâneo: da biossociabilidade à ética (Tese Livre-Docência - Faculdade de Ciências e Letras, Universidade Estadual Paulista, Assis-SP. 91 p.).

Friedman, S. S. (2002). O "falar da fronteira", o hibridismo e a performatividade. Teoria da cultura e identidade nos espaços intersticiais da diferença. Tradução João Paulo Moreira. Eurozine - Revista Clínica de Ciências Sociais, 1-17. Disponível em <http://eurozine.com/ pdf/2002-06-10-friedman-pt.pdf>. Recuperado em 15 de abril de 2008.

Gibson, M. G. (1998). Clínica da perturbação - abordagem transdisciplinar. Revista do Departamento de Psicologia da UFF, 10 (2 e 3), 4-23.

Guattari, F. \& Rolnik, S. (1996). Micropolitica: cartografias do desejo. Petrópolis, RJ: Vozes. 
Hall, S. (2000). Quem precisa da identidade? In: T. T. da Silva (org.). Identidade e diferença: a perspectiva dos estudos culturais (pp. 12-22). Tradução Tomaz Tadeu da Silva. Petropólis, RJ: Vozes.

Junqueira, R. D. (2007). Homofobia: limites e possibilidades de um conceito em meio a disputas. Revista Bagoas: estudos gays, 1(1), 145-166.

Lima, C. A. N. (2009). Direitos fundamentais LGBT. Disponível em <http://carlosalexlima.blogspot.com/2009/11/no-brasil-existem-30-mil-jovens.html>. Recuperado em 16 de março de 2011.

Linhares, J. (2009). Entrevista: Rozângela Alves Justino "Homossexuais podem mudar”. Disponível em <http://veja.abril.com.br/120809/homossexuais-podem-mudar-p-015.shtml>. Recuperado em 29 de agosto de 2009.

López, J. J. O. (s.d.). Víctimas de la homofobia: consecuencias psicológicas. ACGIL - Associació Cristiana de Gays i Lesbianes de Catalunya. Disponível em <http:/www.acgil.org/ documents/246_documents_Victimasdelahomofobia,JorgeOsma.pdf $>$. Recuperado em 12 de fevereiro de 2011.

Miskolci, R. (2007). A Teoria Queer e a questão das diferenças. 16 Congresso de Leitura do Brasil (COLE) - No mundo há muitas armadilhas e é preciso quebrá-las. Campinas: ALB Associação de Leitura do Brasil, 1, 1-19.

Rotello, G. (1998). Comportamento sexual e AIDS: a cultura gay em transformação. Sáo Paulo: GLS. Rubin, G. (1989). Reflexionando sobre el sexo: notas para una teoría radical de la sexualidad. In: C. S. Vence (comp.). Placer y peligro: explorando la sexualidad femenina (pp. 113-190). Madrid: Talasa.

Sanders, G. L. (1994). O amor que ousa declarar seu nome: do segredo à revelação nas afiliações de gays e lésbicas. In: E. Imber-Black (org.). Os segredos na familia e na terapia familiar (pp. 219-244). Tradução de Denise Batista. Porto Alegre: Artes Médicas.

Sedgwick, E. K. (2007). A epistemologia do armário. Cadernos Pagu, 28, $19-54$.

Silva, A. \& Zuba, F. (2009). Drama familiar vira negócio rentável para clínicas. O Tempo, Minas Gerais, 16 nov. 2009. Disponível em <http:/www.otempo.com.br/otempo/ noticias/?IdNoticia=126814>. Recuperado em 16 de março de 2011.

Smith, K. (1971). Homophobia: a tentative personality profile. Psychological report, 29, 1091-1094.

Sullivan, A. (1996). Praticamente normal: uma discussão sobre o homossexualismo. São Paulo: Companhia das Letras.

Toledo, L. G. (2008). Estigmas e estereótipos sobre as lesbianidades e suas influências nas narrativas de histórias de vida de lésbicas residentes em uma cidade do interior paulista (Dissertação de Mestrado. Curso de Pós-Graduação em Psicologia, Universidade Estadual Paulista, Assis, SP. 234f.).

Trevisan, J. S. (1998). Seis balas num buraco só: a crise do masculino. Rio de Janeiro: Record. Welzer-Lang, D. (2001). A construção do masculino: dominação das mulheres e homofobia. Revista de Estudos Feministas, 9(2), 460-482. 


\section{Notas}

${ }^{1} \mathrm{O}$ sufixo ismo, do conceito homossexualismo, criado pelas ciências médicas, tinha como referência o significado de patologia, assim como em reumatismo, hipertireoidismo etc.

${ }^{2}$ Sobre a diferença entre singularidade e identidade, Guattari e Rolnik (1996, pp. 68-69) explicam que "a singularidade é um conceito existencial; já a identidade é um conceito de referenciação, de circunscrição da realidade a quadros de referência. [...] A identidade é aquilo que faz passar a singularidade de diferentes maneiras de existir por um só quadro de referência identificável'.

${ }^{3}$ A estereotipia é a área de manipulação do estigma que pode ser considerada como algo que pertence fundamentalmente à vida pública, ou seja, ela depende das relaçóes com um outro para ser reconhecida enquanto tal. Desta forma, uma pessoa pode carregar o estigma da homossexualidade e ser reconhecida como homossexual pelo fato de apresentar também estereótipos, como, por exemplo, a feminilidade em gays ou masculinidade em lésbicas. Esses estereótipos são cristalizados, sendo tomados como "verdades" essenciais dessas identidades.

${ }^{4}$ Poderíamos considerar que as identidades "convocam" discursivamente todos os corpos e materializam-se performativamente em múltiplos graus, produzindo uma pluralidade de existências e de visibilidades. A ideia de performatividade de Judith Butler em Problemas de gênero (2003) e em Bodies that matter (1993), baseada em Foucault e Althusser, explica que a repetição exaustiva de discursos reguladores e referências (preexistentes ao sujeito) diz a alguém o que ele é ou deixa de ser. Nesse caso, o sujeito, independentemente de seu sexo, de seu desejo, de suas emoçóes, de suas fantasias, é convocado a habitar a linguagem, a regular seu corpo, seus comportamentos a uma ordem discursiva que lhe preconiza um script, um destino (sexual, por exemplo). Desse modo, a identidade precede a própria emergência do corpo.

${ }^{5}$ Sobre a questão da repetibilidade das normas e sua influência na estruturação da identidade, consultar Áran e Peixoto-Júnior, 2007, pp. 133-134.

${ }^{6}$ A heteronormatividade pode ser entendida como a heterossexualidade vista como normal e normativa diante de outras formas de vivência das sexualidades. Deste modo, as normas definidoras da sexualidade "normal" requerem o casal formado por um homem e uma mulher, afetivo-sexualmente complementares, opostos em seus papéis sociais e sexuais - tidos como natural a cada um dos sexos -, monogâmicos e, preferencialmente, dentro da instituição do casamento. Assim, compóem uma ordem social e sexual na qual são postas expectativas e demandas para homens e mulheres, na qual a heterossexualidade é vista como ideal e natural. Tudo o que diverge dessa norma é então classificado como imoral, desviante, aberração, doença, pecado e/ou é invisibilizado (Toledo, 2008, pp. 13-14). 
${ }^{7}$ Algumas feministas rejeitam o termo homofobia por entenderem equivocadamente seu radical homo como um referente de homem - contemplando apenas os homossexuais masculinos como vítimas dessa forma de exclusão. Possivelmente, este seja um dos motivos para a criação das subcategorias de homofobia no movimento LGBT atual: lesbofobia, gayfobia, transfobia, travestifobia, que especificam medos, descréditos, aversóes, ódios, discriminações e violências direcionadas a cada uma das identidades políticas - lésbica, gay, transexual e travesti, respectivamente (Toledo, 2008).

${ }^{8}$ A emergência da militância homossexual, enquanto movimento social, e o aparecimento do HIV/Aids trouxeram questionamentos importantes em torno da problematização da sexualidade, tanto nos espaços íntimos (na privacidade de cada um) quanto públicos.

${ }^{9}$ Organização não-governamental presidida por Rozangela Justino, “[...] cujo objetivo é apoiar pessoas que voluntariamente desejam deixar a homossexualidade". Disponível em <http:// www.athosgls.com.br/noticias_visualiza.php?contcod=20600>. Recuperado em 29 de agosto de 2009.

${ }^{10}$ Dahlheimer \& Feigal, The family that came in from the cold: treating gays, lesbians, and their families. Documento apresentado no Family Therapy Networker Annual Conference. Washington, 1991.

Recebido em 09 de julho de 2011

Aceito para publicação em 05 de janeiro de 2012 